\title{
Role of micrometer sediment particles (SPLITT fractionation) in phosphorus speciation and its recycling in lakes
}

\author{
Tomasz Kowalkowski • Albert Szparaga • \\ Marianna Pastuszak
}

Received: 13 February 2014 / Accepted: 6 July 2014/Published online: 29 July 2014

(C) The Author(s) 2014. This article is published with open access at Springerlink.com

\begin{abstract}
To study the potential of phosphorus (P) release from sediments in the lakes: Chełmżyńskie and Wieczno Płd. was the aim of this study. The task was realized by carrying chemical sequential extractions. The novelty of our approach consists in adopting the SPLITT (split-flow lateral-transport thin) method of particles separation, which was used supplementary to sieving. Sieving provides following sediment fractions: $0.25-0.5,0.125-0.25$, $0.09-0.125 \mathrm{~mm}$, whereas the SPLITT allows separation of particles which smaller than $30 \mu \mathrm{m}$, and which constituted $>30 \%$ of total sediment mass. The mass distribution of size fractions in sediments from both the lakes was very similar. $\mathrm{P}$ content, as the sum of $\mathrm{HCl}-\mathrm{P}, \mathrm{NaOH}-\mathrm{P}, \mathrm{NH}_{4} \mathrm{Cl}-$ $\mathrm{P}$, was by ca. $20 \%$ lower in the particle size fractions $0.25-0.5,0.125-25 \mathrm{~mm}$, whereas total P content in SPLIT sediment was much higher in all size fractions $(<5,5-10$, $10-30 \mu \mathrm{m})$ in the Wieczno Płd. Lake. Although the ecological status is stated to be good in the Wieczno Płd. and moderate in the Chełmżyńskie, the Wieczno Płd. experiences very extensive and frequent algal blooms which form scum on the lake's surface. Based on our findings, we are of the opinion that shallowness of the Lake Wieczno Płd. favors water mixing causing resuspension of fine particles,
\end{abstract}

T. Kowalkowski $(\bowtie) \cdot$ A. Szparaga

Department of Environmental Chemistry and Bioanalytics, Faculty of Chemistry, Nicolaus Copernicus University, ul. Gagarina 7, 87-100 Toruń, Poland

e-mail: pinez@chem.umk.pl

\section{A. Szparaga}

Wojskowe Zakłady Lotnicze Nr 2 S.A, ul. Szubińska 107, 85-915 Bydgoszcz, Poland

M. Pastuszak

National Marine Fisheries Research Institute, ul. Kołłąaja 1, 81-332 Gdynia, Poland which results in enhanced $\mathrm{P}$ internal cycling and thus $\mathrm{P}$ availability for primary producers. Much higher content of phosphorus in the fractions below $30 \mu \mathrm{m}$ in the Wieczno Płd. than the Chełmżyńskie Lake supports our statement.

Keywords SPLITT - Fractionation - Speciation of phosphorus · Lake sediments

\section{Introduction}

Recent decades have seen a massive increase in lake and coastal eutrophication globally, leading to widespread hypoxia and anoxia, habitat degradation, alteration of foodweb structure, loss of biodiversity, and increased frequency, spatial extent, and duration of harmful algal blooms. Eutrophication also decreases the value of rivers, lakes, and estuaries for recreation, fishing, hunting, and esthetic enjoyment (Jeppesen et al. 2005; Schindler 2012; Smith and Schindler 2009; Anderson et al. 2008; Csathó et al. 2007; Heisler et al. 2008; Schindler and Vallentyne 2008; Smal et al. 2005).

Eutrophication is defined as an increase in the rate of supply of organic matter in an ecosystem, which is caused by the enrichment of water bodies by inorganic nutrients (e.g. nitrate, phosphate) (Nixon 1995). It may occur naturally but can also be the result of human activity (cultural eutrophication) and it is particularly evident in rivers, shallow lakes, and coastal areas (Csathó et al. 2007; Duarte 2009; Nixon 2009; Voss et al. 2005; Pastuszak et al. 2003). Cultural eutrophication is the process that speeds up natural eutrophication because of human activity, such as, intensive agriculture with excessive use of fertilizers, deforestation, mining, urbanization, industrialization, irrigation, and damming (Howarth 2008; Humborg et al. 2006; 
Meybeck 2004; Stal et al. 2003; Carpenter et al. 1998; Howarth et al. 1996; Nixon et al. 1996).

Human actions alter the global phosphorus $(\mathrm{P})$ cycle and cause $\mathrm{P}$ to accumulate in some of the world's soil (Filippelli 2002; Bennett et al. 2001). Increasing P levels in the soil elevate the potential $\mathrm{P}$ runoff to aquatic ecosystems (Sharpley 2006; Hooda et al. 2001; Fluck et al. 1992). Melack (1995) and Howarth et al. (1995) report a $50 \%$ to threefold increase in riverine-P flux to the oceans above the pre-agricultural levels. Using a global budget approach, Bennett et al. (2001) estimated the increase in net P storage in terrestrial and freshwater ecosystems to be at least $75 \%$ greater than preindustrial levels of storage.

When entering the sediment in open waters, phosphorus becomes a part of the numerous chemically and biologically mediated processes and is either permanently deposited in the sediments or released by various mechanisms and returned in dissolved form to the water column via interstitial water (Ruttenberg 2003). Since the phosphorus concentration in sediment is much higher than in lake water, phosphorus release can increase the eutrophication of lakes (Hupfer and Lewandowski 2008; Søndergaard et al. 2003; Laseras 1991). The release of P from sediments of eutrophic lakes is often associated with proliferation of nuisance algal blooms, especially cyanobacteria (Hickey and Gibbs 2009). Phosphorus return to circulation in open water is a result of many interrelated biological (e.g. biological immobilization and mobilization), physicochemical (e.g. sorption/desorption, dissolution), and physical processes (e.g. diffusion, bioturbation, wind induced mixing causing resuspension). These processes are affected by a multitude of factors such as: quantity and quality of the deposited organic matter, different sediment characteristics, redox potential, $\mathrm{pH}$, water temperature, microbial activity, dissolved oxygen content, nitrates, and sulfates (Kowalczewska-Madura et al. 2010; Hupfer and Lewandowski 2008; Kim et al. 2003; Ruttenberg 2003; Filippelli 2002; Søndergaard et al. 1996, 2003; Laseras 1991). As shown in recent studies, the grain size of sediment particles is also of importance (Zhu et al. 2013). These parameters define $\mathrm{P}$ speciation in water bodies.

Chemical sequential extractions have been widely used in order to determine various forms in which phosphorus occurs in the sediments (Sobczyński and Joniak 2009a, b; Fytianos and Kotzakioti 2005; Søndergaard et al. 1996, 2003; Kaiserli et al. 2002; Zhou et al. 2001; Rydin 2000). A general aim of sequential extractions is to provide a more precise description of the potentials for phosphorus release from sediment and to predict its future influence on lake water concentrations, thus process of eutrophication. Recent studies indicate that in aquatic systems, not only various forms in which phosphorus occurs in sediment, but also the particle size with adsorbed phosphorus (physical $\mathrm{P}$ speciation) can control bioavailability of P (Selig 2003; Andrieux-Loyer and Aminot 2001).

The aims of our study were (1) supplementary to sieving, to adopt SPLITT method of particles separation in sediment samples collected in the Chełmżyńskie and the Wieczno Południowe (hereafter: Wieczno Płd.) Lakes (central Poland), (2) to carry on the chemical sequential extractions (samples of sediment fractionated according to particle size) in order to receive more extensive information on $\mathrm{P}$ speciation, (3) to specify and compare the potentials for phosphorus release from sediments in both lakes; the internal P cycling can be an important source of this nutrient, and thus, can potentially be responsible for strengthening eutrophication.

\section{Materials and methods}

\section{Study area}

The Wieczno Płd. (Fig. 1), is a moraine, polymictic lake. The lake is located on the North European Plain and on early post-glacial soils which are characterized by high $\mathrm{Ca}$ content $(>25 \mathrm{mg} / \mathrm{L})$ and high vulnerability for degradation. The lake is very shallow with non stratified water column. The average depth reaches only $2.2 \mathrm{~m}$, and there is only one centrally located deep whose depth does not exceed $4.1 \mathrm{~m}$ (Table 1). The water residence time in the Wieczno Płd. Lake is approximately 1.5 year. Water level fluctuations are mostly associated with increased runoff in spring and during the dry periods in summer. The contribution of agricultural land, forest land, and lakes' area to overall catchment area equals to ca. 50, 18, and $27 \%$ (Table 1), respectively. The coastline of the lake is well developed, with trees and scrubs forming a belt along majority of the coastline. Such a belt constitutes a buffer zone effectively limiting surface runoff of water and nutrients. Geomorphology and land cover of the lake's basin speak for rather insignificant diffuse outflow of nutrients. The strongest anthropogenic pressure on the lake is generated by a large tourist complex and use of sandy beach. The monitoring data gathered in 2005 indicated that the ecological state of the lake was good, but with high vulnerability to degradation. Indeed, Schindler's coefficient (limnological parameter, which is a ratio of summed up area of a lake and its catchment area to the lake volume; Kajak 1998) estimated for 2012, was equal to 11.7 .

The Chełmżyńskie Lake is located ca. $12 \mathrm{~km}$ south-east of the Wieczno Płd. Lake. The city of the Chełmża, with about fifteen thousand inhabitants, is located very close to the northern part of the lake (Fig. 1). It is a ribbon lake; the average depth reaches $6 \mathrm{~m}$, whereas the deepest part has the depth of ca. $27 \mathrm{~m}$ (Table 1). The water residence time 


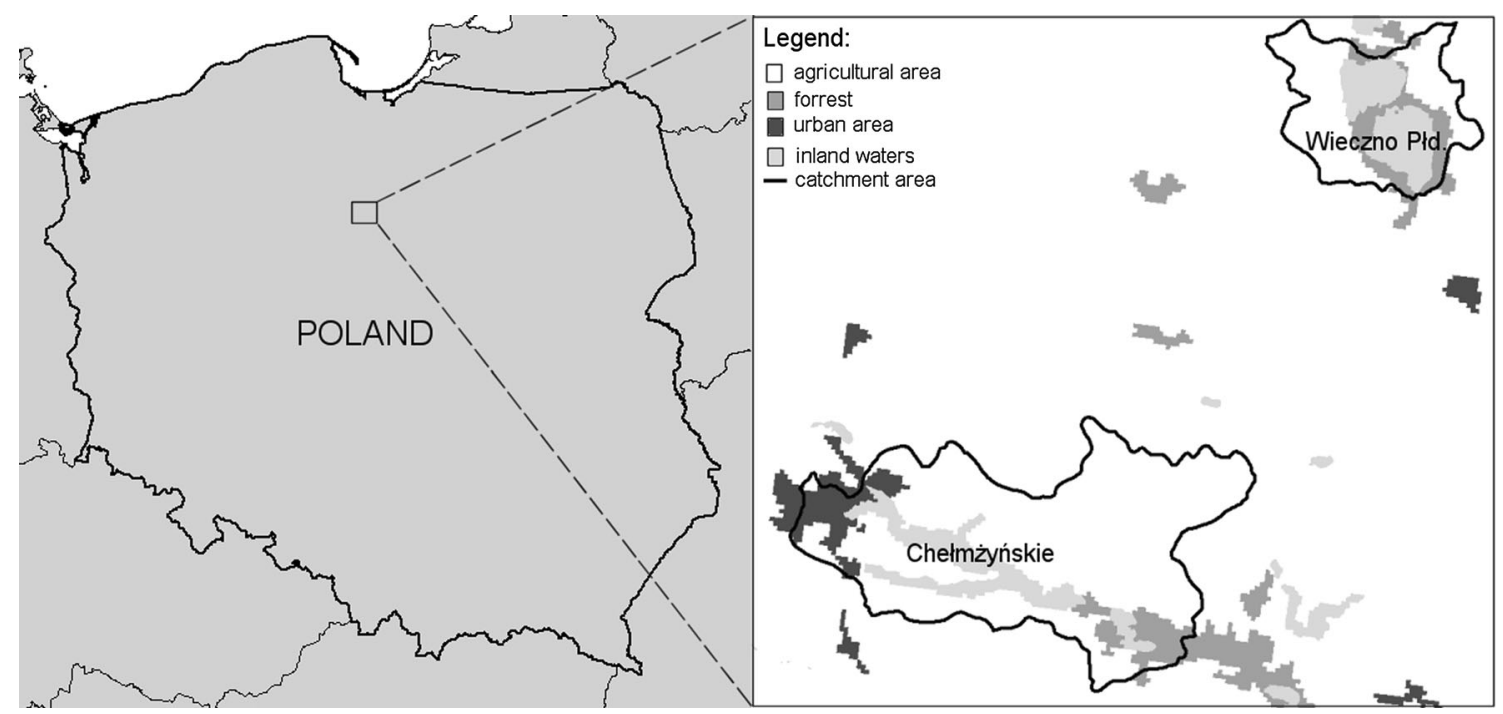

Fig. 1 Site map

Table 1 Comparison of drainage areas of the Chełmżyńskie and Wieczno Płd. Lakes. (source: CLC 2006)

\begin{tabular}{lrl}
\hline Parameter & Chełmżyńskie & Wieczno Płd. \\
\hline Total area [ha] & 271.1 & 199.4 \\
Catchment area [ha] & $3,404.1$ & $5,367.3$ \\
Av. Water volume [m ${ }^{3}$ & 16451 & 4358 \\
Depth max. [m] & 27.1 & 4.1 \\
Depth av. [m] & 6.1 & 2.2 \\
Land use [\%] & & \\
Urban & 5.6 & - \\
Industry & 0.4 & - \\
Arable & 73.6 & 48.7 \\
Pastures & 0.8 & 1.3 \\
Other agricultural land & 2.9 & 5 \\
Forest & 5.3 & 18.2 \\
Wetlands & 0.1 & - \\
Inland waters & 11.5 & 26.8 \\
\hline
\end{tabular}

in the Chełmżyńskie Lake is ca. 3 years. In contrast to the Wieczno Płd. Lake, the water column in the Chełmżyńskie Lake is stratified; in 2012, Schindler's coefficient was equal to 2.16. The hydrologic system of the drainage area consists of artificial melioration streams and two smaller lakes. The coastline of the lake is sinuous, characterized by the presence of a number of bays and peninsulas. The contribution of agricultural land, forest land, and lakes' area to overall catchment area equals to ca. 77.5 and $12 \%$ (Table 1), respectively.

The EU Water Framework Directive (WFD) includes phytoplankton as one of the four biological elements to be used in the assessment of the ecological status of surface waters. According to the criteria of water quality in lakes, specified in WFD and then in the National Monitoring Program Guidance, the Wieczno Płd. Lake had a good ecological status of water in 2012. That opinion was based on the small index of Phytoplankton Metric for Polish Lakes (PMPL) (Napiórkowska-Krzebietke et al. 2012), which turned out to be the smallest in the entire KujawskoPomorskie province. A moderate ecological status was estimated for the Chełmżyńskie Lake, mostly because of elevated values of PMPL index and also the diatom index. In both lakes the average annual water transparency was above good level (WIOŚ Report 2012), but as shown in Table 2, the Secchi depth was ca. two times greater in the Chełmżyńskie than in the Wieczno Płd. Lake in 2005-2012. The ecological status of both lakes is of great importance, because they are valuable water bodies for recreation in the region.

Sampling procedure and basic chemical analyses

The surface $10 \mathrm{~cm}$ sediment samples were collected in spring 2012 in two lakes (Chełmżyńskie and Wieczno Płd.). At each site (Fig. 1), fifteen primary samples were collected with the Beeker type sampler during two cruises. Sampling sites cover the most of the surface of both lakes. The distance between neighboring sampling points was around $500 \mathrm{~m}$ ). The samples were mixed, cleaned from biological residues, such as shells or plants, and homogenized.

Using PN-EN ISO 6878: 2006 method, total phosphorus (TP) content was analyzed in: (1) water samples collected at sampling sites, (2) interstitial water (vacuum filtered from the sediment), (3) dry bulk of sediment 
Table 2 Concentrations total nitrogen, total phosphorus, conductivity of water and Secchi depth readings in the Chełmżyńskie and Wieczno Płd. Lakes

${ }^{a}$ WIOŚ Report (2012)

b WIOŚ (2013)

c The formulation ... (2010)

Fig. 2 Cross-section of SPLITT channel and illustration of separation process

\begin{tabular}{llllll}
\hline Lake & Year & $\begin{array}{l}\text { Secchi } \\
\text { depth }[\mathrm{m}]\end{array}$ & $\begin{array}{l}\text { Conductivity } \\
{[\mu \mathrm{S} / \mathrm{cm}]}\end{array}$ & $\begin{array}{l}\text { Total nitrogen } \\
{[\mathrm{mgN} / \mathrm{L}]}\end{array}$ & $\begin{array}{l}\text { Total phosphorus } \\
{[\mathrm{mgP} / \mathrm{L}]}\end{array}$ \\
\hline Chełmżyńskie & $2012^{\mathrm{a}}$ & 2.7 & 445 & 1.47 & 0.083 \\
& $2011^{\mathrm{b}}$ & 2.1 & 449 & 1.78 & 0.079 \\
& $2010^{\mathrm{b}}$ & 2.5 & 445 & 1.60 & 0.104 \\
& $2009^{\mathrm{b}}$ & 2.6 & 458 & 1.45 & 0.100 \\
& $2008^{\mathrm{c}}$ & 2.4 & 458 & 2.09 & 0.080 \\
Wieczno Płd. & $2012^{\mathrm{a}}$ & 1.0 & 478 & 2.01 & 0.096 \\
& $2005^{\mathrm{c}}$ & 1.7 & 462 & 1.52 & 0.039 \\
\hline
\end{tabular}

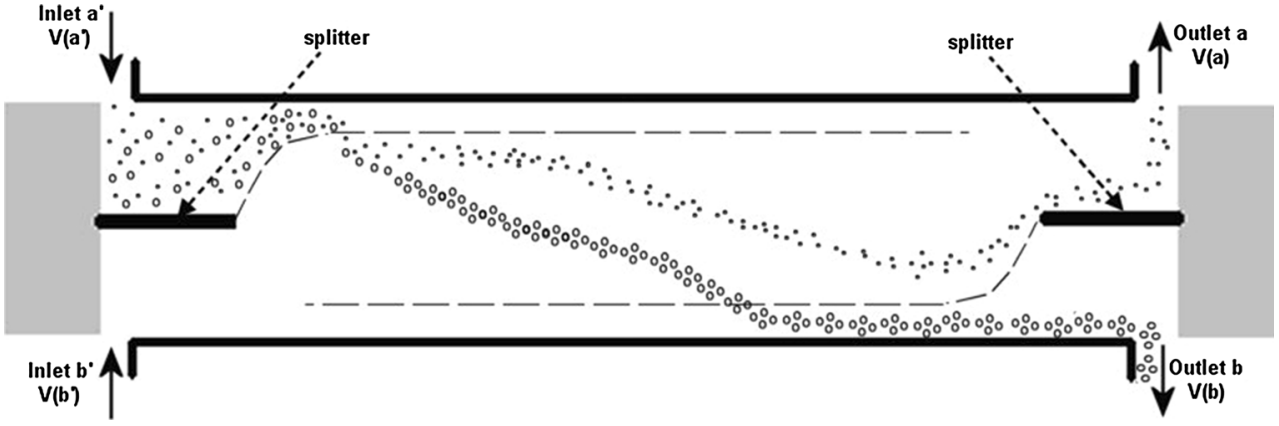

samples. $\mathrm{pH}$ in the liquid samples was measured using combined glass electrode (pHenomenal, VWR, Germany). Carbon content [total carbon (TC) and inorganic carbon (IC)] was analyzed in sediment samples using carbon analyzer TOC 500 equipped with solid state module (Shimadzu, Japan). Standard titration methods were used to determine calcium, magnesium, and total water hardness.

\section{Fractionation}

Classical sieving technique was used to receive three sediment fractions: $0.25-0.5 ; 0.125-0.25 ; 0.09-0.125 \mathrm{~mm}$. The amount of fourth fraction, with diameter of 0.03-0.09 $\mathrm{mm}$, constituted less than $0.1 \%$ of total mass of sediment, therefore this size frame was not taken into the consideration. Particles smaller than $30 \mu \mathrm{m}$ constituted more than $30 \%$ of the total mass and these were fractionated with gravitational split-flow thin channel fractionation technique (SPLITT) using SF1000STD (Postnova Analytics, Landsberg, Germany). The SPLITT technique was developed by Giddings in the early 80's (Giddings, 1985) and has become a semi-preparative sub-technique supplementary to the field-flow fractionation (FFF) family. Separation in SPLITT is based on the same principles as in other FFF methods (Kowalkowski et al. 2006), however, the construction of channel differs. The fractionation channel consists of two inlets and two outlets (Fig. 2). Separation is based on combined action of the laminar flow of a liquid through the channel and transverse gravitational field applied perpendicularly to this flow.

SPLITT has an ability to separate relatively large quantities of sample (milligrams or even grams of dry particles) in reasonable amount of time. Fractionation can be performed in full-feed depletion mode (FFDSF) (Contado et al. 1997; Kowalkowski 2010). In this mode only one upper inlet $\mathrm{a}^{\prime}$ with suspended sample is used (Fig. 2). In such an operational mode the dilution of sample is avoided. A separation mechanism remains nearly the same as in conventional mode with two inlets (Contado et al. 1997). A strategy to remove particles equal or bigger to specific cutoff diameter $\left(\mathrm{d}_{\mathrm{c}}\right)$ is usually applied. Cut-off diameter is related to velocity of transport region described by a simple equation:

$d_{c}^{2}=\frac{18 \eta_{o}}{b L G|\Delta \rho|} V(t)$

where, $\mathrm{V}(\mathrm{t})$ is velocity of transport region, $\mathrm{b}$ and $\mathrm{L}$ are dimensions of SPLITT channel, $\mathrm{G}$ is gravitational constant, $\Delta \rho$ is the difference of density between the particle and the carrier liquid, $\eta$ is carrier liquid viscosity. $V(t)$ is equal to the difference between velocity in the upper inlet $\mathrm{V}\left(\mathrm{a}^{\prime}\right)$ and lower outlet $\mathrm{V}(\mathrm{b})$ multiplied by factor 0.5 . In theory, there are infinite numbers of pairs of $\mathrm{V}(\mathrm{b})$ and $\mathrm{V}\left(\mathrm{a}^{\prime}\right)$ for given $\mathrm{V}(\mathrm{t})$. In practice, however, an appropriate ratio of $\mathrm{V}\left(\mathrm{a}^{\prime}\right)$ to $\mathrm{V}(\mathrm{a})$ has to be optimized to obtain an appropriate resolution and throughput of sample in the same time. In case of the lakes studied, optimized flow rates differed as the density 
Table 3 Selected values of $\mathrm{V}\left(\mathrm{a}^{\prime}\right)$ and $\mathrm{V}(\mathrm{t})$ for fractionation of micrometer particles from sediments collected in the Chełmżyńskie and Wieczno Płd. Lakes

\begin{tabular}{llllll}
\hline Cut-off $[\mu \mathrm{m}]$ & \multicolumn{2}{l}{ Chełmżyńskie } & & Wieczno Płd. & \\
\cline { 2 - 3 } \cline { 5 - 6 } & $\mathrm{V}\left(\mathrm{a}^{\prime}\right)\left[\mathrm{ml} \mathrm{min}^{-1}\right]$ & $\mathrm{V}(\mathrm{t})\left[\mathrm{ml} \mathrm{min}^{-1}\right]$ & & $\mathrm{V}\left(\mathrm{a}^{\prime}\right)\left[\mathrm{ml} \mathrm{min}^{-1}\right]$ & $\mathrm{V}(\mathrm{t})\left[\mathrm{ml} \mathrm{min}^{-1}\right]$ \\
\hline 10 & 55.7 & 41.82 & 16.6 & 22.08 \\
5 & 15.6 & 10.45 & 4.41 & 5.52 \\
\hline
\end{tabular}

Table 4 Particle size distribution of SPLITT fractions

\begin{tabular}{lccc}
\hline & $<5 \mu \mathrm{m}$ & $5-10 \mu \mathrm{m}$ & $10-30 \mu \mathrm{m}$ \\
\hline Chełmżyńskie & & & \\
$\mathrm{d}(0.1)$ & 2.2 & 3.9 & 7.9 \\
$\mathrm{~d}(0.5)$ & 5.2 & 8.2 & 26.7 \\
$\mathrm{~d}(0.9)$ & 7.3 & 12.1 & 83.9 \\
Wieczno Płd. & & & \\
$\mathrm{d}(0.1)$ & 1.0 & 2.8 & 10.7 \\
$\mathrm{~d}(0.5)$ & 4.0 & 9.1 & 34.3 \\
$\mathrm{~d}(0.9)$ & 9.5 & 14.1 & 97.2 \\
\hline
\end{tabular}

of both the sediments was not uniform (Table 3), mostly because of difference in sediments' particle density.

With these values, three additional fractions were collected: $10-30 \mu \mathrm{m}, 5-10 \mu \mathrm{m}$, and smaller than $5 \mu \mathrm{m}$. Particle size distribution of those fractions was checked by light scattering analyzer (Mastersizer 3000, Malvern). The results of these measurement are given in Table 4 , where $\mathrm{d}(0.1), \mathrm{d}(0.5)$, and $\mathrm{d}(0.9)$ stand for particle diameter in 10 , 50 and $90 \%$ of cumulative volume of particle size distribution chart.

\section{Sequential extraction description}

The amount of material collected with sieves (fractions: $0.25-0.5 \mathrm{~mm}$; $0.125-0.25 \mathrm{~mm}$; $0.09-0.125 \mathrm{~mm}$ ) was large enough to perform the additional measures of chemical $\mathrm{P}$ speciation. In order to characterize various $\mathrm{P}$ species in lake sediments, a sequential extraction scheme by Psenner et al. (1984), with some modifications by Hupfer et al. (1995), was used in our study. The fractions, which covered also sub-micrometer ones (Table 4), were as follows:

1. $\mathrm{NH}_{4} \mathrm{Cl}-\mathrm{P}-$ labile (desorbed, hydrolyzed) loosely bound or adsorbed phosphorus extractable with water solution of $\mathrm{NH}_{4} \mathrm{Cl}$ gives an estimate of readily available $\mathrm{P}$ for phytoplankton

2. Fe-P-bound with iron hydroxide surfaces and iron oxides, extractable with water solution of sodium hydrocarbonate and sodium thiosulfacte; $\mathrm{P}$ bound to Fe-hydroxides and Mn compounds is redox sensitive and it is considered as a potentially mobile pool of $\mathrm{P}$

3. $\mathrm{NaOH}-\mathrm{P}-$ bound with aluminium and organic matter and extractable with water solution of $\mathrm{NaOH}$; this
Table 5 General characteristics of unfractionated sediments and as well as lake water in the Chełmżyńskie and Wieczno Płd. Lakes

\begin{tabular}{lll}
\hline & Chełmżyńskie & Wieczno Płd. \\
\hline Sediment & & \\
pH & $7.17 \pm 0.34$ & $7.92 \pm 0.43$ \\
TC $[\%]$ & $14.77 \pm 2.15$ & $6.79 \pm 0.48$ \\
IC $[\%]$ & $2.15 \pm 0.65$ & $1.38 \pm 0.32$ \\
TP $\left[\mu \mathrm{gP} / \mathrm{dm}^{3}\right]$ in interstitial water & $186.6 \pm 2.1$ & $194.3 \pm 3.3$ \\
Water & & \\
pH & 7.87 & 7.92 \\
Total hardness $\left[\mathrm{mg} / \mathrm{dm}^{3}\right]$ & 266.4 & 280.4 \\
Calcium hardness $\left[\mathrm{mg} / \mathrm{dm}^{3}\right]$ & 171 & 190.7 \\
Magnesium hardness $\left[\mathrm{mg} / \mathrm{dm}^{3}\right]$ & 95.4 & 89.7 \\
TP $\left[\mu \mathrm{gP} / \mathrm{dm}^{3}\right]$ & 95.32 & 94.49 \\
\hline
\end{tabular}

fraction can be released for the growth of phytoplankton when anoxic conditions prevail at the sediment/ water interface

4. The HCl-P-bound with calcium and extractable with water solution of $\mathrm{HCl}$; this fraction is sensitive to low $\mathrm{pH}$ and it is assumed to mainly consist of apatite $\mathrm{P}$ (natural and detritus) including $\mathrm{P}$ bound to carbonates and traces of hydrolysable organic $\mathrm{P}$

5. Res.-P-residual, permanently bound with matrix after complete mineralization.

Phosphorus concentrations were measured in the first four fractions, whereas $\mathrm{P}$ content in the fifth, Res.-P fraction was neglected, as the latter was very small and constituted less than $0.001 \%(\mathrm{w} / \mathrm{w})$. The relative standard deviations were smaller than $3 \%$; therefore, they are not included in figures presented. All the analyses were done in three repetitions.

\section{Results}

General characteristics of the sediments prior to the fractionation i.e. $\mathrm{pH}$, contribution of total carbon (TC) and inorganic carbon (IC), total phosphorus concentrations (TP) in interstitial water, as well as general characteristic of water i.e. $\mathrm{pH}$, total hardness, calcium and magnesium hardness, and TP content in lakes' water are presented in 
Fig. 3 Mass distribution of size fractions in sediment samples from the Chełmżyńskie and Wieczno Płd. Lakes

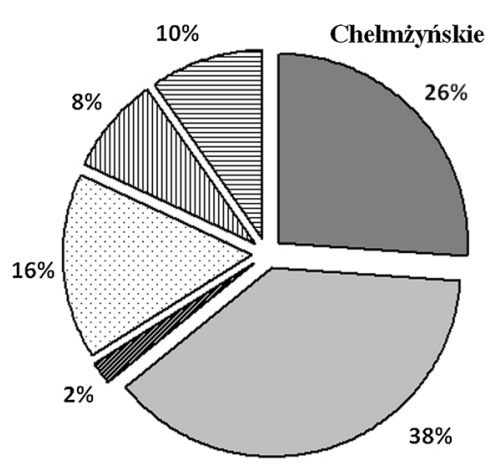

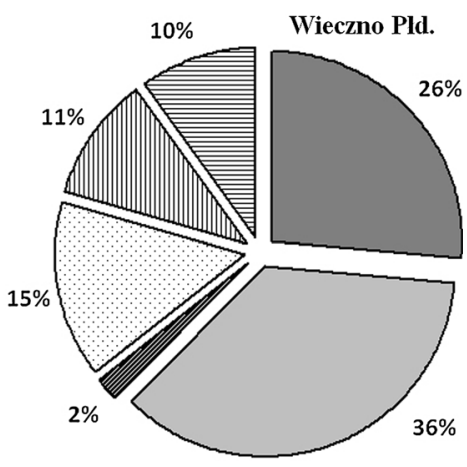

Table 5. Numbers written in bold indicate that the parameters significantly differ between both the lakes ( $t$ test, $P=0.05$ ).

Both, the sediment and the water samples were slightly alkaline. Total carbon (TC) content was considerably higher in the sediment of the Chełmżyńskie Lake. The amount of inorganic carbon (IC) in the Chełmżyńskie Lake constituted ca. $15 \%$ of TC, whereas in the Wieczno Płd. Lake that contribution reached ca. $20 \%$, but at much smaller overall TC content. Total phosphorus in the interstitial water was significantly higher in the Wieczno Płd. Lake. As to water parameters, significant difference concerns total and calcium hardness (Table 5). The percentage contribution of mass in all six fractions obtained during grain size fractionation is presented in Fig. 3. The pattern is very similar for both lakes, with the exception of slightly higher contribution of $0.125-0.25 \mathrm{~mm}$ fraction and slightly lower contribution of $10-30 \mu \mathrm{m}$ fraction in the Wieczno Płd. Lake. Majority of the material has the diameter above $90 \mu \mathrm{m}(65.3$ and $63.2 \%$ for the Chełmżyńskie and the Wieczno Płd., respectively). Smaller, more mobile particles constituted about $45 \%$ of the collected material, with slightly higher contribution (by $2 \%$ ) in the Wieczno Płd. Lake.

Phosphorus speciation analysis using Psenner's sequential extraction scheme were initially performed in unfractionated sediment samples (Fig. 4). TP content in the sediment sample from the Chełmżyńskie Lake was higher than from the Wieczno Płd. Lake by about $20 \%$ and it was estimated at $0.84 \mathrm{mgP} / \mathrm{g}$. Distribution pattern of $\mathrm{P}$ speciation forms was very similar in both the lakes. Above $25 \%$ of phosphorus was loosely bounded with sediment material ( $\mathrm{NH}_{4} \mathrm{Cl}-\mathrm{P}$ fraction). Majority of phosphorus was bounded with calcium-HCl-P and constituted ca. $50 \%$ of TP. Phosphorus accumulated in this form can be released only under severe acidifying conditions. The rest of $\mathrm{P}$ (ca. $35 \%$ ) was bounded with iron and aluminum. The largest difference between the $\mathrm{P}$ forms in the lakes studied was observed in the case of $\mathrm{Fe}-\mathrm{P}$, whose content was twice as high in the Chełmżyńskie Lake (14\%) in comparison with that in the

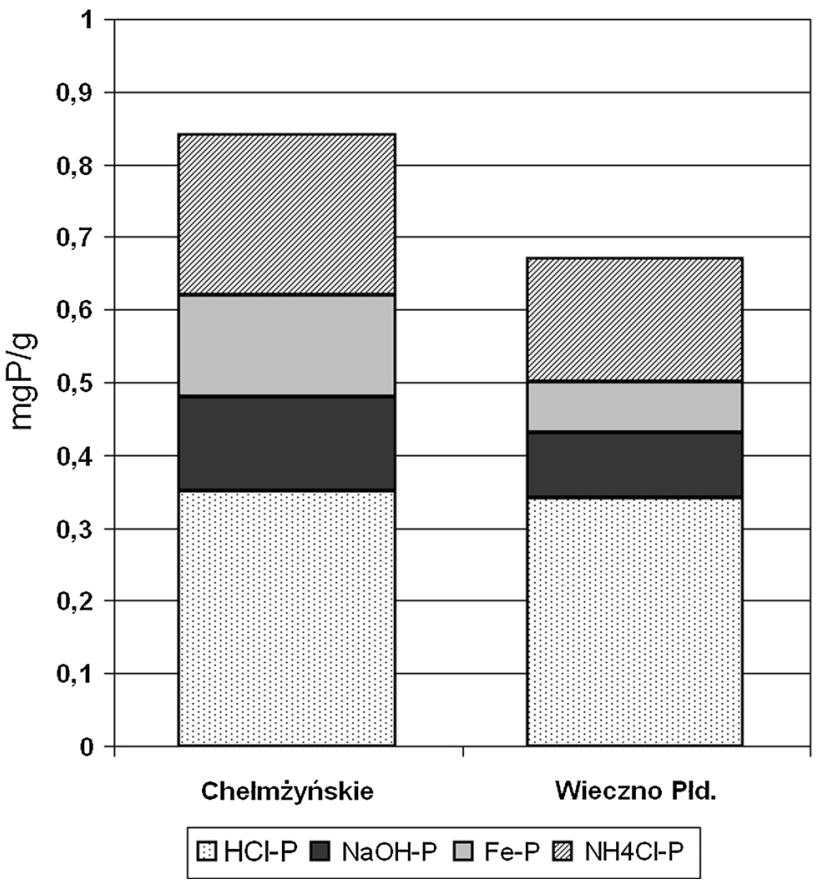

Fig. 4 Phosphorus content in fractions in sediment samples which were not particle size separated-the Chełmżyńskie and Wieczno Płd. Lakes

Wieczno Płd. Lake (7\%). Such a picture of P speciation should lead to similar eutrophication intensity in both the lakes. In reality, the Wieczno Płd. Lake shows symptoms of enhanced eutrophication, with more frequent and extensive algal blooms, the latter confirmed by lower Secchi depth readings as compared with the Chełmżyńskie Lake (WIOŚ Report 2012; Table 2). Investigation of phosphorus content in fractions isolated by sieving and SPLITT fractionation gives the explanation of this fact.

The Psenner extraction conducted in fractions obtained by sieving gave different distribution pattern of phosphorus speciation than in un-fractionated samples (Figs. 4, 5, 6). Analysis revealed that in both fractions $(0.25-0.5$ and $0.125-0.25 \mathrm{~mm}$ ) about 45 and $46 \%$ of phosphorus was bounded with aluminium or organic matter (NaOH-P) and 


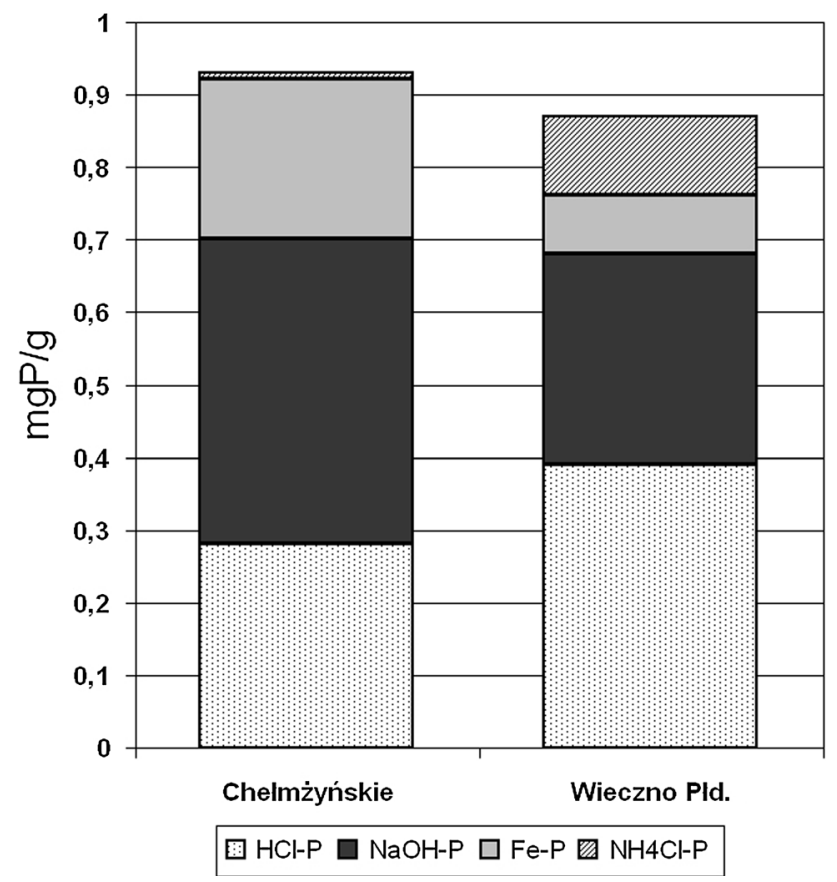

Fig. 5 Phosphorus content in $0.25-0.5 \mathrm{~mm} \mathrm{P}$ fractions from the Chełmżyńskie and Wieczno Płd. Lakes

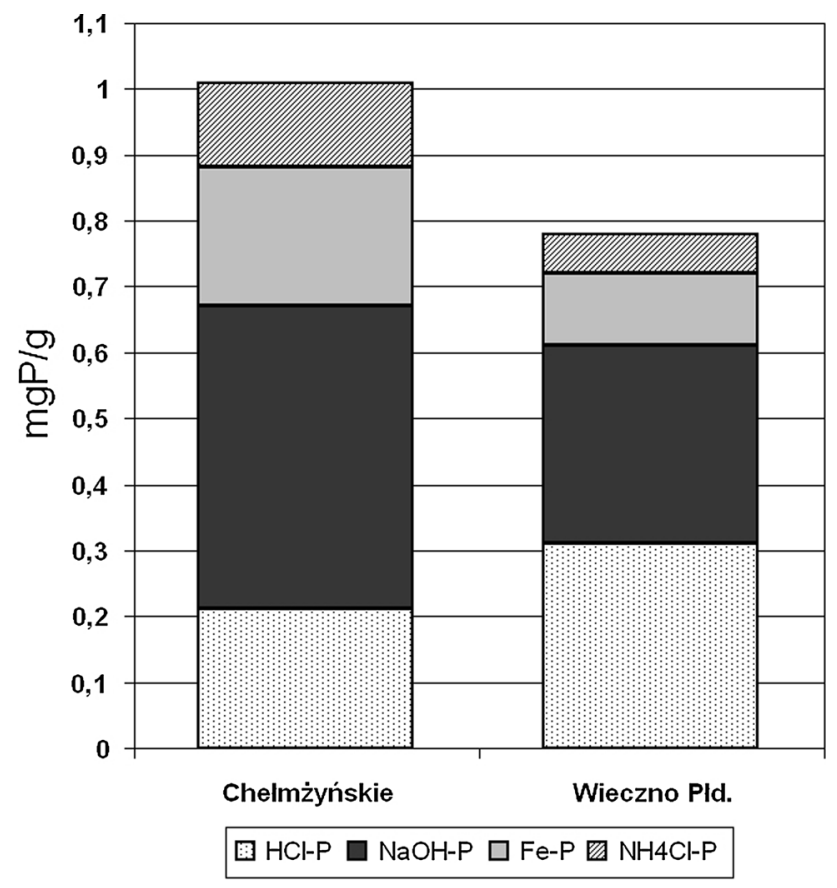

Fig. 6 Phosphorus content in $0.125-0.25 \mathrm{~mm} \mathrm{P}$ fractions from the Chełmżyńskie and Wieczno Płd. Lakes

this form was predominating in the Chełmżyńskie Lake (Figs. 5, 6). In the Wieczno Płd. Lake, contribution of $\mathrm{P}$ bounded with calcium (HCL-P) was either highest (Fig. 5) or comparable (Fig. 6) with $\mathrm{NaOH}-\mathrm{P}$ fraction (aluminium bounded $\mathrm{P}$ ) and that amounted to 33 or up to $45 \%$. These

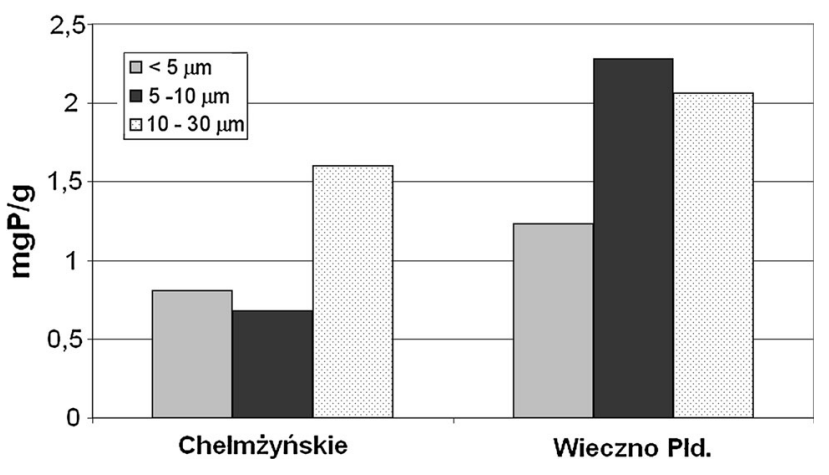

Fig. 7 Total phosphorus content in SPLITT sediment size fractions from the Chełmżyńskie and Wieczno Płd. Lake

pools of $\mathrm{P}$ are relatively immobile. The most labile phosphorus fraction $\left(\mathrm{NH}_{4} \mathrm{Cl}-\mathrm{P}\right)$ reached only $1 \%$ in 0.25-0.5 mm fraction in the Chełmżyńskie Lake (Fig. 5) and remained in the range $8-13 \%$ in the Wieczno Lake (Figs. 5, 6). Generally, the content of phosphorus was increasing with the decrease of particle size (Figs. 5, 6). In $0.125-0.25 \mathrm{~mm}$ fraction of sediment from the Chełmżyńskie Lake the $\mathrm{P}$ total concentration was highest, reaching $1.01 \mathrm{mgP} / \mathrm{g}$.

Generally, a similar trend of TP increase with decreasing particle size is observed in fractions derived by SPLITT system (Fig. 7). However, one should note that total $\mathrm{P}$ concentrations in fractions separated by SPLITT were on average by $40 \%$ higher when compared with numbers seen in Figs. 4, 5. The highest TP concentrations, reaching $2.28 \mathrm{mg} / \mathrm{g}$ for fraction $5-10 \mu \mathrm{m}$, were observed in the case of sediments from the Wieczno Płd. Lake. Unfortunately, mass of fractions was too small to perform SPLITT speciation analysis. It has to be pointed out, that the amount of labile phosphorus $\left(\mathrm{NH}_{4} \mathrm{Cl}-\mathrm{P}\right)$ was considerably higher in non-fractionated material (Fig. 4) than in major fractions (Figs. 5, 6). Such a difference has to be compensated by relatively high share of $\mathrm{NH}_{4} \mathrm{Cl}-\mathrm{P}$ extractable forms in micrometer size fractions obtained by SPLITT.

\section{Discussion}

Increased urbanization and sewage disposal, regulation of wetlands and streams and more intensive farming practices have increased the nutrient loading to many of the lakes world-wide. This has resulted in major changes in the biological structure and dynamics of the lakes and often in a shift from a clear to a turbid state (Sobczyński and Joniak 2013; Schindler 2012; Fisher et al. 2009; Smal et al. 2005). Phosphorus generally enters aquatic ecosystems sorbed to soil particles that are eroded into lakes, streams, and rivers. (Sharpley 2006). The sediment-bound phosphorus includes $\mathrm{P}$ associated with soil particles and organic material eroded 
during flow events and constitutes $60-90 \%$ of P transported in surface runoff from most cultivated land (Sharpley 2006). Much of P runoff occurs during major erosion-causing storms (Pionke et al. 1997). Potential $P$ pollution of aquatic ecosystems is thus strongly influenced by watershed land use and the concentration of $\mathrm{P}$ in watershed soils. Factors that increase erosion or the amount of $\mathrm{P}$ in the soil should be considered as strengthening the potential P runoff to downhill aquatic ecosystems (Daniel et al. 1994; Sharpley et al. 1994). As proven by Sobczyński and Joniak (2009a, b), even at negligible impact of diffuse outflow, the shallow lake ecosystem functioning can be substantially disturbed by exclusive long-term impact of point source discharges.

The catchment area of the Chełmżyńskie Lake is by $26 \%$ smaller than that of the Wieczno Płd. Lake, but that smaller watershed is characterized by (1) 1.5 times larger relative contribution of arable land, (2) presence of urban settlements, and industry which are non-existent in catchment of the Wieczno Płd. Lake, (3) 3.5 times lower contribution of forested area as compared with the catchment of Wieczno Płd. Lake, (4) twice as high contribution of TC, and by 1.5 times higher contribution of IC in comparison with values found in the Wieczno Płd. (Table 5). These parameters may be indicative for stronger anthropogenic pressure in the Chełmżyńskie Lake. On the other hand, one should be aware of the fact that potentially more polluted waters draining the catchment of the Chełmżyńskie Lake feed nearly 4 times larger volume of this lake as compared with the volume of the Wieczno Płd. Lake (Table 1). The fact is that the Wieczno Płd. Lake is much more sensitive, as algal blooms are more frequent and extensive, the latter confirmed by low Secchi depth readings (Table 2). So, the reasons of such a situation must be sought out somewhere else, not only in land cover/use, even if these parameters are commonly known as primary driving forces of excessive $\mathrm{N}$ and $\mathrm{P}$ emission, leading to eutrophication.

Phosphorus release mechanisms in lakes

At a process-oriented level, the $\mathrm{P}$ release from sediments represents only one part of the whole lake internal $\mathrm{P}$ turnover because particulate $\mathrm{P}$ is continuously converted into dissolved $\mathrm{P}$ in all lake compartments (Hupfer and Lewandowski 2008). Phosphorus can be released from the sediment depths as low as $20 \mathrm{~cm}$ (Søndergaard et al. 2003) but the upper $10-15 \mathrm{~cm}$ layer of sediments is actively involved in physicochemical exchange with the water column. Lake sediments can be very different and highly variable regarding chemical composition. Parameters such as dry weight, organic content, and content of iron, aluminum, manganese, calcium and other elements with capacity to bind and release phosphorus may all influence sediment-water interactions (Søndergaard et al. 1996).

Hupfer and Lewandowski (2008) further prove that (a) P retention of the lake sediment strongly depends on sediment characteristics and land use of the catchment, (b) the presence of redox-insensitive P-binding systems such as $\mathrm{Al}(\mathrm{OH})_{3}$, irreducible $\mathrm{Fe}(\mathrm{III})$ minerals can enhance the $\mathrm{P}$ retention and completely prevent $P$ release even in case of anoxic conditions, (c) alternative release mechanisms such as a dissolution of calcium-bound $\mathrm{P}$ and decomposition of organic $\mathrm{P}$ under both, aerobic and anaerobic conditions are often more important than redox driven by Fe-coupled $\mathrm{P}$ cycle, (d) role of bacteria in $\mathrm{P}$ cycling is of importance because they affect $\mathrm{P}$ cycling not only by altering the redox conditions but also by releasing $\mathrm{P}$ during mineralization of organic matter. Studies of Boström et al. (1982) and Jensen and Andersen (1992) show that shallow lakes have often demonstrated phosphorus release to oxic lake water, suggesting that other factors than redox conditions at the sediment-water interface are involved. Søndergaard et al. (2003) emphasize the importance of high sediment surface: water column ratio in shallow lakes, which means that the potential influence on lake water concentrations is stronger than in deeper lakes.

The maximum and the average depths in the Chełmżyńskie Lake equal to 27.1 and $6.1 \mathrm{~m}$, whereas in the Wieczno Płd. they reach 4.1 and $2.2 \mathrm{~m}$ (Table 1). Though $\mathrm{P}$ concentration in interstitial waters was by ca. $8 \mu \mathrm{gP} / \mathrm{dm}^{3}$ higher in the Wieczno Płd. Lake, P concentrations in water column did not differ very much in both lakes (Table 4 ). Very shallow and only by $30 \%$ smaller (by surface) Wieczno Płd. Lake, as compared with the Chełmżyńskie Lake, is characterized by a high sediment surface, water column and by large active bottom. Role of these parameters in supply in epilimnetic waters in shallow lakes has been emphasized by Søndergaard et al. (2003) and Kowalczewska-Madura et al. (2010). Thus, more frequent and intense algal blooms in the Wieczno Płd. Lake in summer and autumn can be explained by the morphology of the lake but also by much higher content of phosphorus in the fractions below $30 \mu \mathrm{m}$ (Fig. 7). These particles in the case of a shallow reservoir can be quite easily resuspended and $\mathrm{P}$ released into the water column and in the conditions of strong water mixing may be responsible for the seasonal increase in eutrophication of the reservoir. In deep lakes, the nutrients potentially released from the sediment are accumulated in the often oxygen-poor hypolimnion during summer and thus become difficult to access for primary producers. In contrast, in shallow lakes the well-mixed conditions create an immediate interaction between the sediments and the photic zone's pools of nutrients and primary producers during the whole growth season. In shallow and wind-exposed lakes frequent 
resuspension may also result in an overall summer accumulation of organic matter in the lake, as decomposition primarily occurs in the water column. In less wind-exposed lakes, sedimentation is permanent over most of the lake bottom and the sediment content of nutrients is more uniform (Nixdorf and Deneke 1995).

Based on our findings, we are of the opinion that shallowness of the Lake Wieczno Płd. favors water mixing causing resuspension of fine particles, which results in enhanced $\mathrm{P}$ internal cycling and thus $\mathrm{P}$ availability for primary producers. Much higher content of phosphorus in the fractions below $30 \mu \mathrm{m}$ in the Wieczno Płd. than the Chełmżyńskie Lake supports our statement.

Acknowledgments This work was supported by the Polish National Science Centre (NCN) project no. N N305 300140 and by the National Marine Fisheries Research Institute in Gdynia, Poland (funds provided for statutory activity of the Institute).

Open Access This article is distributed under the terms of the Creative Commons Attribution License which permits any use, distribution, and reproduction in any medium, provided the original author(s) and the source are credited.

\section{References}

Anderson DM et al (2008) Harmful algal blooms and eutrophication: examining linkages from selected coastal regions of the United States. Harmful Algae 8:39-53

Andrieux-Loyer F, Aminot A (2001) Phosphorus forms related to sediment grain size and geochemical characteristics in French coastal areas. Estuar Coast Shelf Sci 52:617-629

Bennett EM, Carpenter SR, Caraco NF (2001) Human impact on erodible phosphorus and eutrophication: a global perspective. Bioscience 51(3):227-234

Boström B, Jansson M, Forsberg C (1982) Phosphorus release from lake sediments. Arch Hydrobiol Beih Ergebn Limnol 18:5-59

Carpenter SR et al (1998) Nonpoint pollution of surface waters with phosphorus and nitrogen. Ecol Appl 8(3):559-568

CLC (2006) http://clc.gios.gov.pl/index.php?IdCss=0

Contado C, Dondi F, Beckett R, Giddings JC (1997) Separation of particulate environmental samples by SPLITT fractionation using different operating modes. Anal Chim Acta 345:99-110

Csathó P et al (2007) Agriculture as a source of phosphorus causing eutrophication in Central and Eastern Europe. Soil Use and Management, British Society of Soil Sciences 23(Suppl. 1): $36-56$

Daniel TC, Sharpley AN, Edwards DR, Wedepohl R, Lemunyon JL (1994) Minimizing surface water eutrophication from agriculture by phosphorus management. J Soil Water Conserv 49:30-38

Duarte CM (2009) Coastal eutrophication research: a new awareness. Hydrobiologia 629:263-269

Filippelli GM (2002) Global phosphorus cycle. Rev Mineral Geochem 48:391-425

Fisher J, Barker T, James C, Clarke S (2009) Water quality in chronically nutrient-rich lakes: the example of the ShropshireCheshire meres. Freshwater Rev 2:79-99

Fluck RC, Fonyo C, Flaig E (1992) Land-use-based phosphorus balances for Lake Okeechobee, Florida, drainage basins. App Eng in Agric 8:813-820
Fytianos K, Kotzakioti A (2005) Sequential fractionation of phosphorus in lake sediments of northern Greece. Environ Monit Assess 100:191-200

Giddings JC (1985) A system based on split-flow lateral-transport thin (SPLITT). Separation cells for rapid and continuous particle fractionation. Sep Sci Technol 20:749-768

Heisler $\mathbf{J}$ et al (2008) Eutrophication and harmful algal blooms: a scientific consensus. Harmful Algae 8:3-13

Hickey CW, Gibbs MM (2009) Lake sediment phosphorus release management - Decision support and risk assessment framework. New Zeal J Marine Fresh 43:819-856

Hooda PS et al (2001) Manuring and fertilization effects on phosphorus accumulation in soil and potential environmental implications. Adv Environ Res 5:13-21

Howarth RW (2008) Coastal nitrogen pollution: a review of sources and trends globally and regionally. Harmful Algae 8:14-20

Howarth RW, Jensen HS, Marino R, Postma H (1995) Transport to and processing of $\mathrm{P}$ in near-shore and oceanic waters. In: Tiessen $\mathrm{H}$ (ed) Phosphorus in the global environment: transfers, cycles and management. SCOPE. Wiley \& Sons, Chichester, UK, pp 323-345

Howarth RW et al (1996) Regional nitrogen budgets and riverine N, P fluxes for the drainages to the North Atlantic Ocean: natural and human influence. Biogeochemistry 35:75-139

Humborg C, Pastuszak M, Aigars J, Siegmund H, Mörth CM, Ittekkot V (2006) Decreased silica land-sea fluxes through damming in the Baltic Sea catchment-significance of particle trapping and hydrological alterations. Biogeochemistry 77:265-281

Hupfer M, Lewandowski J (2008) Oxygen controls the phosphorus release from lake sediments-a long-lasting paradigm in limnology-review paper. Internat Rev Hydrobiol 93(4-5):415-432

Hupfer M, Gächter R, Giovanoli R (1995) Transformation of phosphorus species in settling seston and during early sediment diagenesis. Aquat Sci 57:305-324

Jensen HS, Andersen FØ (1992) Importance of temperature, nitrate, and $\mathrm{pH}$ for phosphate release from aerobic sediments of four shallow, eutrophic lakes. Limnol Oceanogr 37:577-589

Jeppesen E et al (2005) Lake restoration and biomanipulation in temperate lakes: relevance for subtropical and tropical lakes. In: Reddy V (ed) Tropical lakes: their restoration and management. Science Publishers, Enfield, N.H., pp 1147-1155

Kaiserli A, Voutsa D, Samara C (2002) Phosphorus fractionation in lake sediments - Lakes Volvi and Koronia, N. Greece, Chemosphere 46:1147-1155

Kajak Z (1998) Hydrobiology-limnology. Inland water ecosystems, PWN, Warsaw, p 355

Kim LH, Choi E, Stenstrom MK (2003) Sediment characteristics, phosphorus types and phosphorus release rates between river and lake sediments. Chemosphere 50(1):53-61

Kowalczewska-Madura K, Gołdyn R, Dondajewska R (2010) Phosphorus release from the bottom sediments of Lake Rusałka (Poznań, Poland). Oceanol Hydrobiol Stud 39(4):135-144

Kowalkowski T (2010) Characterization of natural organic colloids derived from sewage sludge. Pol J Environ Stud 2:437-441

Kowalkowski T, Contado C, Dondi F, Buszewski B (2006) Field-flow fractionation: theory, techniques, applications and the challenges. Crit Rev Anal Chem 36:129-135

Laseras PL (1991) Sedimentary phosphorus dynamics in epicontinental systems: a literature review. Oecol Aquat 10:113-125

Melack JM (1995) Transport and transformations of $\mathrm{P}$ in fluvial and lacustrine ecosystems. In: Tiessen $\mathrm{H}$ (ed) Phosphorus in the Global Environment. SCOPE, 15th edn. Wiley\& Sons, Chichester, UK, pp 245-254

Meybeck MH (2004) The global change of continental aquatic systems: dominant impacts of human activities. Water Sci Technol 49(7):73-83 
Napiórkowska-Krzebietke A, Hutorowicz A, Pasztaleniec A (2012) Phytoplankton metrics response to the increasing phosphorus and nitrogen gradient in shallow lakes. J Elem 17(2):289-303

Nixdorf B, Deneke R (1995) Why "very shallow" lakes are more successful opposing nutrient loads. Hydrobiologia 342/343: 269-284

Nixon SW (1995) Coastal marine eutrophication: a definition, social causes, and future concerns. Ophelia 41:199-219

Nixon SW (2009) Eutrophication and the macroscope. Hydrobiologia 629:5-19

Nixon SW et al (1996) The fate of nitrogen and phosphorus at the land-sea margin of the North Atlantic Ocean. Biogeochemistry $35: 141-180$

Pastuszak M, Nagel K, Grelowski A, Mohrholz V, Zalewski M (2003) Nutrient dynamics in the Pomeranian Bay (southern Baltic): impact of the Oder River outflow. Estuaries 26(5):1238-1254

Pionke HB, Gburek WJ, Sharpley AN, Zollweg JA (1997) Hydrologic and chemical controls on phosphorus loss from catchments. In: Tunney H, Carton OT, Brookes PC, Johnston AE (eds) Phosphorus loss from soil to water. CAB International, New York

Psenner R, Pucsko R, Sager M (1984) Die Fraktionierungorganischer und anorganischer Phosphorverbindungenvon Sedimenten: versuch einer Definition ökologischwichtiger Fraktionen. Arch. Hydrobiol. Suppl. 70:111-155

Ruttenberg KC (2003) Treatise on Geochemistry 8. In: Schlesinger WH, Holland HD, Turekian KK (eds) The global phosphorus cycle., p 682

Rydin E (2000) Potentially mobile phosphorus in Lake Erken sediment. Wat Res 34(7):2037-2042

Schindler DW (2012) The dilemma of controlling cultural eutrophication of lakes. Proc R Soc B 279(1746):4322-4333

Schindler DW, Vallentyne JR (2008) The algal bowl: overfertilization of the world's freshwaters and estuaries, 2nd edn. University of Alberta Press, Edmonton, Canada

Selig U (2003) Particle size-related phosphate binding and P-release at the sediment-water interface in a shallow German lake. Hydrobiologia 492(1):107-118

Sharpley AN (2006) Agricultural Phosphorus management: Protecting Production and Water Quality. Lesson 34. Agricultural Research Service. Mid West Plan Service. Iowa State University, Ames, Iowa 50011-3080; http://www.lpes.org/Lessons/Les son34/34_Phosphorus_Management.html

Sharpley AN, Chapra SC, Wedepohl R, Sims JT, Daniel TC, Reddy KR (1994) Managing agricultural phosphorus for protection of surface waters: issues and options. J Environ Qual 23(3): $437-451$
Smal H, Kornijów R, Ligęza S (2005) The effect of catchment on water quality and eutrophication risk of five shallow lakes (Polesie region, Eastern Poland). Pol J Ecol 53(3):313-327

Smith VH, Schindler DW (2009) Eutrophication science: where do we go from here? Trends Ecol Evol 24(4):2001-2007

Sobczyński T, Joniak T (2009a) Vertical changeability of physicalchemical features of bottom sediments in three lakes, in aspect type of water mixis and intensity of human impact. Pol J Environ Stud 18(6):1093-1099

Sobczyński T, Joniak T (2009b) Differences in composition and proportion of phosphorus fractions in bottom sediments of Lake Góreckie (Wielkopolska National Park). Environ Prot Eng 35(2):90-95

Sobczyński T, Joniak T (2013) The variability and stability of water chemistry in deep temperate lake: results of long-term study of eutrophication. Pol J Environ Stud 22(1):221-230

Søndergaard M, Windolf J, Jeppesen E (1996) Phosphorus fractions and profiles in the sediment of shallow Danish lakes as related to phosphorus load, sediment composition and lake chemistry. Wat Res 30(4):992-1002

Søndergaard M, Peder J, Jeppsen E (2003) Role of sediment internal loading of phosphorus in shallow lakes. Hydrobiologia 506-509:135-145

Stal L et al (2003) BASIC: baltic Sea cyanobacteria. An investigation of the structure and dynamics of water blooms of cyanobacteria in the Baltic Sea-responses to changing environment. Cont Shelf Res 23:1695-1714

The formulation of water use restrictions of the lakes or reservoirs and their catchment area. 2010. Regional Water Management Authority in Cracow, http://www.rzgw.gda.pl/cms/site.files/file/ RDW_2011/RZGW_Gdansk.pdf

Voss M, Liskow I, Pastuszak M, Rüß D, Schulte U, Dippner JW (2005) Riverine discharge into coastal bay: a stable isotope study in the Gulf of Gdańsk, Baltic Sea. J Mar Syst 57:127-145

WIOŚ Report (2012) Report on state of environment in KujawskoPomorskie province in 2012, Biblioteka Monitoringu Środowiska, Bydgoszcz, 125 pp. [in Polish] http://www.wios.bydgoszcz. pl/images/stories/pdf/raport2012.pdf

WIOŚ (2013) http://www.wios.bydgoszcz.pl/webmapa/wody/

Zhou Q, Gibson C, Zhu Y (2001) Evaluation of phosphorus bioavailability in sediments of three contrasting lakes in China and the UK. Chemopshere 42:221-225

Zhu Y, Zhang R, Wu F, Qu X, Xie F, Fu Z (2013) Phosphorus fractions and bioavailability in relation to particle size characteristics in sediments from Lake Hongfeng. Southwest China. Environ Earth Sci 68(4):1041-1052 